\title{
Factors Influencing Importance of Country of Brand and Country of Manufacturing in Consumer Product Evaluation
}

\author{
Jashim Uddin ${ }^{1,2}$, Shehely Parvin ${ }^{3,4} \&$ Md. Lutfur Rahman ${ }^{1}$ \\ ${ }^{1}$ Department of Business Administration, East West University, Dhaka, Bangladesh \\ ${ }^{2}$ Department of Marketing and Management, Macquarie University, Sydney, Australia \\ ${ }^{3}$ Department of Marketing, University of Dhaka, Dhaka, Bangladesh \\ ${ }^{4}$ School of Marketing, University of Technology Sydney, Sydney, Australia \\ Correspondence: Jashim Uddin, Department of Marketing and Management, Macquarie University, Sydney, \\ NSW 2109, Australia. E-mail: jashim.uddin@mq.edu.au
}

\author{
Received: September 18, 2012 Accepted: January 16, 2013 Online Published: January 25, 2013 \\ doi:10.5539/ijbm.v8n4p65 \\ URL: http://dx.doi.org/10.5539/ijbm.v8n4p65
}

\begin{abstract}
Bangladesh, a developing country, has significant import dependence since its inception. This study attempted to identify the factors influencing significance of country of brand and country of manufacturing in consumer product evaluation. Two models, one for country of brand and another for country of manufacturing tested in this study. Regression models for country of brand and country of manufacturing demonstrate statistical significance with $\mathrm{R}^{2}$ value of .970 and .935 respectively. The determinants posed statistically significant influence for country of brand are technological superiority, price level, reliability, performance, and durability; while significant variables influencing country of brand are price level, value for money, and aesthetical design.
\end{abstract}

Keywords: COO, country of brand, country of manufacturing, product evaluation

\section{Introduction}

Country of origin (COO) is considered as one of the most extensively researched concepts in international consumer research (Jain, 2007; Peterson \& Jolibert, 1995; Tan \& Farley, 1987). Paradoxically, COO has been designated as one of the least understood concepts (Verlegh \& Steenkamp, 1999) after a long systematic research history, which was initiated by Schooler (1965). Even after this criticism, the intensity of study in this area has not diminished. More specifically, COO related studies have generated more than 1000 published works since the 1960s (Papadopoulos, 2004). In contrast, the influence of COO on buyer perceptions was endorsed by several studies and meta-analysis (Bilkey and Nes, 1982; Demirbag et al., 2010; Papadopoulos and Heslop, 1993; Peterson and Jolibert, 1995; Pharr, 2005; Phau and Chao, 2008; Sharma, 2011; Verlegh and Steenkamp, 1999) and a vital role of $\mathrm{COO}$ on business activities and performance was stated by many practitioners (Colyer, 2005). Over the time, the scope of COO research has become more complex with increased number of studies and constantly changing nature of globalization. As an intersection construct (Usunier, 2011), COO has alignments with other concepts like countries, products, and consumers (Usunier, 2011).

COO has been highly researched as a quality cue for product evaluation (Baughn and Yaprak, 1993; Chao, 1993; Erickson et al., 1984; Han, 1989; Han and Terpstra, 1988; Hong and Wyer, 1989, 1990; Johansson, 1989; Papadopoulous et al., 1988, 1990; Parameswaran and Yaprak, 1987; Yaprak and Parameswaran, 1986). But, increased availability of foreign sourced products and expanding domain of multinational enterprises (MNEs) have reshaped $\mathrm{COO}$ importance as a quality cue. Consequently, the 'made in' label has been decomposed into 'country of design', 'country of assembly', and 'country of parts'. In case of consumer products, 'country of parts' are not readily viewable and in some cases not clearly specified. As globalization took a forefront in the recent past that permit MNEs to take advantage of spreading production facilities around the globe. Producing products from low cost countries allowed MNEs to gain price competitiveness in global marketplace (Baatz, 1999; Grimn, 1992; Saporito, 1992; Serwer, 1995; Welch, 1994). Moreover, they took advantage of standardizing already established brand names over several markets. According to Tse and Gorn (1993), products produced in one country and branded in another is a common phenomenon of economic globalization. As a consequence of such activities, $\mathrm{COB}$ and $\mathrm{COM}$ started to play role in consumers' evaluative domain and 
therefore concerned $\mathrm{COO}$ researchers.

Country of manufacture $(\mathrm{COM})$ and country of brand (COB) play important role in consumer product evaluations of quality and decision making (Thakor \& Lavack, 2003; Hulland, 1999; Iyer \& Kalita, 1997; Thakor \& Kohli, 1996; Maheswaran, 1994). But, academic COO researchers are in disagreement regarding the supremacy of one over other. Han and Terpstra (1988) and Tse and Gorn, (1993) reported larger effect of COM on product evaluations than COB. Whereas, Hui and Zhou (2003) and Srinivasan et al. (2004) found that COB makes greater influence on product evaluations than COM when both the information presented simultaneously. As the importance of both the cues is evidenced in literature, the factors influencing importance of $\mathrm{COB}$ and COM image can add new insight to COO literature.

Additionally, importance of $\mathrm{COO}$ information to consumers are now under the question of relevance than ever before after the publication of Usunier (2006). Later, Usunier (2011) endorsed the importance of origin information by consumers and outlined that this importance is experiencing a shift from $\mathrm{COO}$ and $\mathrm{COM}$ to COB. But, it is not easy to disregard the importance of COM. For instance, COB of 'Ford' is very well known around the world but produced and or assembled in more than 20 countries. As market conditions differ, quality adjustments usually take place. According to motoring writer Barry Park (2012), "One German manufacturer recently switched the factory source of its vehicles from South Africa back to Germany because of quality concerns. A Japanese manufacturer did the same after testing the quality of its Thailand plant for nine months". Moreover, Consumers rate quality of developed country produced cars more favorably than developing country assembled cars (Johansson and Nebezahl, 1986; Han and Terpstra, 1988). In addition, perceived quality of strong and weak brands can be reduced because of choosing lower quality COM (Cordell, 1992; Han and Terpstra, 1988; Tse and Gorn, 1993; Witt and Rao, 1992).

Bangladeshi consumers, usually ask for $\mathrm{COO}$ because of significant import dependence and less availability of locally produced products. Consumer durables, which are considered as high involvement products in emerging economy settings, require extensive information search before purchase decision making. Among consumer durables, refrigerator market in Bangladesh is significantly influenced by COB and COM. The array of COB in Bangladeshi market is quite diverse and the prominent names are Kelvinator, Whirlpool, Samsung, LG, Fisher \& Paykel, Ariston, Kelon, Hisense, Hair, Singer, Vestfrost, Panasonic, Sharp, General, Hitachi, Walton, etc. In converse, numbers of countries representing COM are mostly emerging economies such as China, Malaysia, Thailand, New Zealand etc.

\section{Objectives of the Study}

This study intends to achieve the following outcomes:

1) Identifying multiple variables that explain $\mathrm{COB}$ and $\mathrm{COM}$ image.

2) Uncovering the significance of explanatory variables.

3) Developing models for $\mathrm{COB}$ and $\mathrm{COM}$ that explain the strength of association between dependent variable and independent variables.

4) Determining the level of influence by each explanatory variable on dependent variable.

\section{Methodology}

This investigation is based on survey data. Before collecting data, three academics from Marketing specialization suggested some variables that can explain importance of COB and COM image. $\mathrm{COO}$ widely been studied as a product quality cue, but as an abstract term this study considered decomposition product quality into performance, reliability, durability, aesthetics, warranty/serviceability (Garvin, 1988; for simplification five commonly understandable criteria taken out of eight). Later, a group of consumers and refrigerator retail outlet managers were invited to a focus group discussion to opine about the possible factors that explain importance of $\mathrm{COB}$ and $\mathrm{COM}$ image. Considering the input from all the above specified parties, one common set of variables finalized for both $\mathrm{COB}$ and $\mathrm{COM}$ image importance. The study took place in Chittagong, known as port city of Bangladesh.

The steps in sampling design given below:

\subsection{Target Population}

Refrigerator is a household product and therefore its purchase decision depends on family. This study focused households as sampling unit, but the questionnaire will be filled by an individual chosen by family members who played major role in making refrigerator purchase. Making responses to our questionnaire require households using refrigerator for a long time, having good knowledge about brands, higher education levels, and higher 
income levels. Within an emerging economy setting, higher income group use refrigerator(s) for long time, higher purchase capacity allows more options to evaluate; higher educational level enables access to wider information about products, brands, $\mathrm{COO}$ etc.

\subsection{Sampling Technique}

We have identified five residential areas of Chittagong city, where higher income group people normally reside. Then we have selected two areas randomly. After that, applying systematic sampling method based on unique holding number 267 prospective respondents identified. Among them $89 \%$ found appropriate as respondents. Out of 237 respondents finally 223 for COB image and 210 for COM image were taken into account because of incomplete and inconsistencies in responses.

Structured questionnaire used for primary data collection. Dependent variable for COB investigation was 'explain importance of $\mathrm{COB}$ image' and for COM investigation was 'explain importance of COM image'. Both the dependent variables measured by five point interval scale where ' 5 ' indicated strongly agree and ' 1 ' indicated strongly disagree. Independent variables were also measured by five point interval scale. We used multiple regression analysis as the statistical tool to get the desired results.

\section{Hypotheses Development}

As specified earlier one set of variables finalized that may influence importance COB and COM image regarding refrigerators. The hypotheses are consecutively placed in the following using one statement for $\mathrm{COB}$ and $\mathrm{COM}$ :

H1: To understand more about the reliability of a refrigerator more the importance of $\mathrm{COB}$ or $\mathrm{COM}$ image.

H2: Greater understanding of durability requires greater importance of $\mathrm{COB}$ or $\mathrm{COM}$ image.

H3: More the understanding required about aesthetical design of a refrigerator more the importance of COB or COM image.

H4: Higher understanding of availability perception needs higher emphasis to be given on COB or COM image.

H5: Greater understanding about a refrigerator's performance necessitates greater importance of COB or COM image.

H6: Higher the requirement of the price level perception higher the importance to be given on $\mathrm{COB}$ or $\mathrm{COM}$ image.

H7: More the knowledge for technological superiority required higher the importance of understanding COB or COM image.

H8: Greater the perception required about value for money greater the importance of COB or COM image.

H9: For understanding more of warranty perception more the importance of COB or COM image.

\section{Proposed Model}

This study proposes two CLRM (classical linear regression model), one for understanding importance of COB image and another for understanding importance of COM image using the same set of independent variables. The Models are as follows:

$Y($ COBimage $)=\alpha+\beta 1($ reliability $)+\beta 2($ durability $)+\beta 3($ aestheticaldesign $)+\beta 4($ availability $)+\beta 5($ performance $)+$

$\beta 6$ (price level) $+\beta 7$ (technological superiority $)+\beta 8$ (value for money $)+\beta 9($ warranty $)+\varepsilon$

$Y($ COMimage $)=\alpha+\beta 1($ reliability $)+\beta 2($ durability $)+\beta 3($ aestheticaldesign $)+\beta 4($ availability $)+\beta 5($ performance $)+$

$\beta 6($ price level $)+\beta 7$ (technological superiority $)+\beta 8$ (value for money $)+\beta 9($ warranty $)+\varepsilon$

Where,

$Y$ indicates dependent variable 'importance of COB image'/ 'importance of COM image', $\alpha$ is constant term, $\beta 1$, $\beta 2 \ldots \beta 9$ are the coefficients of explanatory variables, and $\varepsilon$ is the error term.

\section{Results of Multiple Regression Analysis}

Various combinations of explanatory variables were employed to get the model fit. Additionally, combinations of explanatory variables were made to minimize the problem of multicollinearity (linear relationship between or among explanatory variables) as far as possible, as the assumptions of CLRM is that there is no multicollinearity among the explanatory variables included in the regression model (Gujarati, 2003).

As the study investigated importance of COB and COM separately, analyses regarding COB model and COM models are presented sequentially in the following. 
Table 1. COB model summary

\begin{tabular}{ccccc}
\hline Model & R & R Square & Adjusted R square & Std. Error of the Estimate \\
\hline 1 & 0.985 & 0.971 & 0.970 & 0.19382 \\
\hline
\end{tabular}

According to Table 1, the explanatory variables can explain $97 \%$ of the total variability of the dependent variable ' $Y$ (COB image)' as the adjusted $\mathrm{R}^{2}$ of the model is 0.970 .

Table 2. ANOVA for COB model

\begin{tabular}{cccccc}
\hline Model & Sum of squares & df & Mean Square & F & Sig. \\
\hline 1 Regression & 273.848 & 5 & 54.770 & 1457.893 & .000 \\
Residual & 8.152 & 217 & .038 & & \\
Total & 282.000 & 222 & & & \\
\hline
\end{tabular}

The ANOVA table (Table 2) for COB model shows the significance of the combined effect of explanatory variables in the regression model (calculated $\mathrm{F}$ statistic 1457.893). So, we can reject the null hypothesis $(\beta k=0)$ and accept the alternate hypothesis $(\beta k \neq 0)$ at $1 \%$ level of significance.

Table 3. Coefficients of explanatory variables for COB model

\begin{tabular}{|c|c|c|c|c|c|c|c|}
\hline \multirow[t]{2}{*}{$\begin{array}{c}\text { Explanatory Variables for } \\
\text { COB Model }\end{array}$} & \multicolumn{2}{|c|}{$\begin{array}{l}\text { Unstandardized } \\
\text { coefficients }\end{array}$} & \multirow{2}{*}{$\begin{array}{c}\text { Standardized } \\
\text { coefficients }\end{array}$} & \multirow[b]{2}{*}{$\mathrm{t}$} & \multirow[b]{2}{*}{ Sig. } & \multicolumn{2}{|c|}{$\begin{array}{l}\text { 95\% Confidence Interval for } \\
\text { B }\end{array}$} \\
\hline & B & Std. Error & & & & Lower Bound & Upper Bound \\
\hline Constant & -5.952 & 193 & & -30.893 & .000 & -6.332 & -5.572 \\
\hline Reliability & .725 & .034 & .358 & 21.418 & .000 & .658 & .792 \\
\hline Durability & .238 & .017 & .240 & 13.599 & .000 & .203 & .272 \\
\hline Performance & .281 & .021 & .267 & 13.082 & .000 & .239 & .323 \\
\hline Price level & .913 & .043 & .377 & 21.169 & .000 & .828 & .998 \\
\hline Technological Superiority & .957 & .033 & .469 & 29.372 & .000 & .892 & 1.021 \\
\hline
\end{tabular}

The contribution of each explanatory variable represented by individual coefficient $(\beta)$ values, which appear in the Table 3. Table 3 indicates the explanatory variables' significance for the COB model, where it is noticeable that five explanatory variables are included in the regression model and other four are excluded. Exclusion of four explanatory variables (availability, aesthetical design, value for money, warranty) was done to get a higher $\mathrm{R}^{2}$, to obtain acceptable significance of explanatory variables individually, and to reduce multicollinearity problems. The variance in the dependent variable explained by each explanatory variable is expected to be independent. As multicollinearity is essentially a sample phenomenon, the significant distinction is not between the existence and nonexistence of multicollinearity, but between its various degrees (Gujarati, 2003). So, evidence regarding the extent of multicollinearity in regression models is required.

Table 4. Collinearity statistics for COB model

\begin{tabular}{lcc}
\hline \multirow{2}{*}{ Explanatory Variables for COB Model } & \multicolumn{2}{c}{ Collinearity Statistics } \\
\cline { 2 - 3 } & Tolerance & VIF \\
\hline Reliability & .478 & 2.094 \\
Durability & .427 & 2.341 \\
Performance & .319 & 3.138 \\
Price level & .420 & 2.378 \\
Technological Superiority & .522 & 1.915 \\
\hline
\end{tabular}


Table 4 indicates that the multicollinearity problem in COB regression model is not considerable. As a rule of thumb, if VIF of a variable exceeds 10 then we can consider it as a serious multicollinearity problem (Kleinbaum, Kupper, and Muller; 1988). So, we can assert that collinearity among five explanatory variables is within considerable limit. As another measure of collinearity, TOL (Tolerance) for all the five variables are not close to zero (closer the TOL to zero the greater the degree of collinearity, as according to Gujarati; 2003) and hence, both theoretical understanding of the explanatory variables and collinearity statistics direct us to accept the model.

Table 5. COM model summary

\begin{tabular}{ccccc}
\hline Model & $\mathrm{R}$ & $\mathrm{R}$ Square & Adjusted R square & Std. Error of the Estimate \\
\hline 1 & 0.967 & 0.936 & 0.935 & 0.35301 \\
\hline
\end{tabular}

Regarding COM investigation results, the explanatory variables can explain $93.5 \%$ of the total variability of the dependent variable ' $Y$ (COM image)' as the adjusted $\mathrm{R}^{2}$ of the model is 0.935 (Table 5).

Table 6. ANOVA for COM Model

\begin{tabular}{cccccc}
\hline Model & Sum of squares & df & Mean Square & F & Sig. \\
\hline 1 Regression & 374.025 & 3 & 124.675 & 1000.484 & .000 \\
Residual & 25.671 & 206 & .125 & & \\
Total & 399.695 & 209 & & & \\
\hline
\end{tabular}

The ANOVA table (Table 6) for COM model shows the significance of the combined effect of explanatory variables in the regression model (calculated $\mathrm{F}$ statistic 1000.484). So, we can reject the null hypothesis $(\beta k=0)$ and accept the alternate hypothesis $(\beta k \neq 0)$ at $1 \%$ level of significance.

Table 7. Coefficients of explanatory variables for COM model

\begin{tabular}{|c|c|c|c|c|c|c|c|}
\hline \multirow[t]{2}{*}{$\begin{array}{c}\text { Explanatory Variables for } \\
\text { COM Model }\end{array}$} & \multicolumn{2}{|c|}{$\begin{array}{l}\text { Unstandardized } \\
\text { coefficients }\end{array}$} & \multirow{2}{*}{$\begin{array}{c}\text { Standardized } \\
\text { coefficients }\end{array}$} & \multirow[b]{2}{*}{$\mathrm{t}$} & \multirow[b]{2}{*}{ Sig. } & \multicolumn{2}{|c|}{ 95\% Confidence Interval for B } \\
\hline & B & Std. Error & & & & Lower Bound & Upper Bound \\
\hline Constant & -3.652 & .332 & & -10.998 & .000 & -4.307 & -2.997 \\
\hline Aesthetical design & 496 & .068 & .155 & 7.289 & .000 & .362 & .630 \\
\hline Price level & .933 & .046 & .740 & 20.207 & .000 & .842 & 1.024 \\
\hline Value for money & .431 & .050 & .329 & 8.582 & .000 & .332 & .530 \\
\hline
\end{tabular}

The contribution of each explanatory variable represented by individual coefficient $(\beta)$ values, which appear in the Table 7. Table 7 indicates the explanatory variables' significance for the COM model, where it is shown that only three explanatory variables are included in the regression model and remaining six are excluded (reliability, durability, availability, performance, technological superiority, warranty).

Table 8. Collinearity statistics for COM model

\begin{tabular}{lcc}
\hline \multirow{2}{*}{ Explanatory Variables for COM Model } & \multicolumn{2}{c}{ Collinearity Statistics } \\
\cline { 2 - 3 } & Tolerance & VIF \\
\hline Aesthetical design & .687 & 1.455 \\
Price level & .233 & 4.298 \\
Value for money & .212 & 4.724 \\
\hline
\end{tabular}


Table 8 indicates that the multicollinearity problem in COM regression model is not significant (as the highest VIF statistics is 4.724 and lowest TOL is .212). According to different judgemental basis, the COM model conforms to acceptability criteria.

\section{Interpretations of Results}

Table 1 indicates that the multiple coefficient of determination $\left(\mathrm{R}^{2}\right)$ is 0.970 that means the explanatory variables can explain about $97 \%$ of the variance in dependent variable COB image. According to the specification of Theil (1978), using adjusted $\mathrm{R}^{2}$ is better than using $\mathrm{R}^{2}$. Moreover, adjusted $\mathrm{R}^{2}$ of 0.97 is considerably high when the variables are perceptive in nature and not measurable by absolute value (ratio scale).

Table 2 explains the dependability of the model as the F statistic shows very high value and appeared significant at $1 \%$ level.

Table 3 shows significant explanatory variables with the level of contribution by each explanatory variable to explain the dependent variable ' $Y(C O B$ image $)$ '. The beta coefficients of explanatory variables indicate their intensity to explain the dependent variable. Though there is a debate regarding the use of standardized and unstandardized coefficient, more preference should be given on standardized coefficient when measurement is made by interval scale, and not by absolute values (ratio scale). Coincidentally, there is no difference between the sequencing by unstandardized and standardized beta $(\beta)$ coefficients. According to unstandardized and standardized beta $(\beta)$ coefficients the explanatory variables in descending order are technological superiority (.957, .469), price level $(913, .377)$, reliability $(.725, .358)$, performance $(.281, .267)$, and durability $(.238, .240)$.

The study results support that to understand about the technological superiority of a refrigerator, importance of COB image is highest. In other words, when the COB image is higher that indicates higher technological superiority to refrigerator customers and users. Price level perception of customers also varies according to the $\mathrm{COB}$ image, meaning that a customer will perceive higher price of a refrigerator having brand origin in Japan than in China. COB image is also important to customers in understanding reliability of refrigerators and higher $\mathrm{COB}$ image means higher product reliability to them. Regarding the performance of refrigerator, $\mathrm{COB}$ plays important role in forming customer perception. In understanding durability of refrigerator, customers put importance on $\mathrm{COB}$ image.

The revised model for $\mathrm{COB}$ image after the statistical analysis is in the following:

$Y($ COB image $)=\alpha+\beta 1$ (reliability $)+\beta 2($ durability $)+\beta 3($ performance $)+\beta 4($ price level $)+\beta 5($ technological superiority) $+\varepsilon$

Table 5 showing that the multiple coefficient of determination $\left(\mathrm{R}^{2}\right)$ is 0.935 that means the explanatory variables can explain about $93.5 \%$ of the variation in the dependent variable COM image. And adjusted $\mathrm{R}^{2}$ of 0.935 is considerably high when the variables are based on human subjective judgement and not measurable by absolute value.

Table 6 explains the dependability of the model as the F statistic shows very high value and appeared significant at $1 \%$ level.

Table 7 shows significant explanatory variables with the level of contribution by each explanatory variable to explain the dependent variable ' $Y$ (COM image)'. The beta coefficients of explanatory variables indicate their intensity to explain the dependent variable. Though there is a debate regarding the use of standardized and unstandardized coefficient, more preference should be given on standardized coefficient when measurement is made by interval scale, and not by absolute values (ratio scale). There is little difference between the sequential order made by unstandardized beta $(\beta)$ coefficients and the sequential order made by standardized beta $(\beta)$ coefficients. According to unstandardized beta $(\beta)$ coefficients, the explanatory variables in descending order are price level (.933), aesthetical design (.496), and value for money (.431). And according to standardized beta ( $\beta$ ) coefficients the explanatory variables in descending order are price level (.740), value for money (.329), and aesthetical design (.155).

The study results demonstrate that to understand about the price level of a refrigerator, importance of COM image is highest. In another way, when the COM image is higher that indicates higher price level to refrigerator customers and users. COM image is also important to customers in understanding value for money of refrigerators and higher $\mathrm{COM}$ image means higher value for money to them. This finding may create confusion as grater COM image will lead to higher price and may generate lesser value to customers. Regarding the aesthetical design of refrigerator, COM plays important role in forming customer perception. That means, country with higher COM image normally produce refrigerators with more impressive aesthetical design. 
The revised model for COM image after the statistical analysis is in the following:

$$
Y(\text { COM image })=\alpha+\beta 1 \text { (aesthetical design })+\beta 2(\text { price level })+\beta 3(\text { value for money })+\varepsilon
$$

After identifying best model fit for $\mathrm{COB}$ and $\mathrm{COM}$, two variables named as availability and warranty are not appeared statistically considerable in any of the models.

\section{Implications for International Marketing}

The study results provide striking evidence of $\mathrm{COO}$ significance at the time when $\mathrm{COO}$ research facing question of relevance. $\mathrm{COB}$ and $\mathrm{COM}$, as a relevant $\mathrm{COO}$ decomposition, play important role in forming customer perception. The results of two models' testing generate significant implications for international marketers.

Reliability of a product is assessed through COB not COM. In other words, higher COB image indicate reliability to customers and higher $\mathrm{COB}$ image with lower $\mathrm{COM}$ image not harming the reliability perception of customers for refrigerators. Similarly, COB image is important for understanding product durability and COM image is not playing such role as durability is not a significant explanatory variable in COM model. That means possible durability discounting for lower COM image is not a significant factor to the customers.

Customers' assessment of refrigerator performance can be understandable by COB image but not by COM image. As similar to other quality measures stated above, performance of refrigerator is perceived by customers on the basis of COB image. When customers evaluate technological superiority, they consider COB image not COM image as according to this study findings. So, combination of high COB image and low COM image may not be detrimental to the customer perception regarding technological superiority of refrigerator.

Customers consider both $\mathrm{COB}$ and $\mathrm{COM}$ image for forming up their price perception of a product as the price level appears as a very important explanatory variable for both the models of this study. It is important to be noted for international marketers that by using higher COB image and lower COM image charging high prices may not be possible. Moreover, customers may ask for COM information when knowing about the price and then make their own evaluation regarding price acceptability.

Aesthetical design is an important indicator of quality and its relevance for refrigerator is worthwhile. The study findings revealed that perception about aesthetics depends on COM image and not on COB image. Therefore, it is perceived by the customers that multinational producers sacrifice aesthetical part of refrigerators when producing from low image country. Moreover, customers having higher importance for aesthetics may find COM information more relevant.

Value for money usually indicates to a fair exchange. It is perceived that higher brand image leads to premium prices and therefore the value for money reduces. This perception becomes more relevant in the present competitive world because of more available options in competitive prices. This study finding indicates that greater understanding about value for money can be explained by COM image and not by COB image. This finding reaffirms that charging higher prices only for higher COB image without higher COM image is not well acceptable to customers. Therefore, regarding the value assessment customers look for COM image.

Availability and warranty are two important considerations for purchasing imported products. But, these two variables were excluded by regression analysis for both the models. One possible explanation can be that refrigerator is a high involvement product and customers are not searching for availability over the time rather customers start searching for this products at the time of requirement. Such situation let customers unaware of availability. For highly mechanical products, warranty reduces perceived risk regarding a purchase. But, warranty services mostly provided by local agents in Bangladesh that let customers not to relate COB and COM image with it.

\section{Limitations of the Study}

The study reflects the view of refrigerator users of higher income group, though they are the major users of refrigerators in Bangladesh, therefore will not be generalizable to other user groups. Moreover, the considered group of people have understandability about the COB and COM because of their higher educational levels that is not representing the larger refrigerator users in Bangladesh. Selection of two residential areas out of five, saved cost and time that is a usual limitation of sampling procedure.

\section{Conclusion}

The study revealed empirical evidence of $\mathrm{COB}$ and $\mathrm{COM}$ image importance by the customers in emerging economy settings. Moreover, different set of significant variables have been identified for the two models under consideration. High adjusted $\mathrm{R}^{2}$ value for both the models signifies the strength of relationship between explanatory variables and dependent variables. In addition, implications of significant variables will be worthy 
input for international refrigerator producers and marketers in designing country of association decisions. Results of this study also support higher relevance of COB image than COM image from the perspective of customer product evaluation that is consistent with the study results of Hui and Zhou (2003) and Srinivasan et al. (2004).

\section{References}

Baatz, E. (1999). How purchasing handles intense cost pressure. Purchasing, 126, 61-66.

Baugh, C. C., \& Yaprak, A. (Eds.). (1993). Mapping Country-of-Origin Recent Developments and Emerging Research Avenues. New York: International Business Press.

Bilkey, W. J., \& Nes, E. (1982). Country-of-origin Effects on Product Evaluations. Journal of International Business Studies, 13(Spring/Summer), 89-100. http://dx.doi.org/10.1057/palgrave.jibs.8490539

Chao, P. (1993). Partitioning Country of Origin Effects: Consumer Evaluations of a Hybrid Product. Journal of International Business Studies, 24(2), 291-306. http://dx.doi.org/10.1057/palgrave.jibs.8490851

Cordell, V. (1992). Effects of consumer preferences for foreign sourced products. Journal of International Business Studies, 23(2), 251-269. http://dx.doi.org/10.1057/palgrave.jibs.8490267

Demirbag, M., Sahadev, S., \& Mellahi, K. (2010). Country image and consumer preference for emerging economy products: the moderating role of consumer materialism. International Marketing Review, 27(2), 141-63. http://dx.doi.org/10.1108/02651331011037494

Erickson, G. M., Johansson, J. K., \& Chao, P. (1984). Image Variables in Multi-Attribute Product Evaluations: Country-of-Origin Effects. Journal of Consumer Research, 11(2), 694-699. http://dx.doi.org/10.1086/209005

Garvin, D. A. (1987). Competing on the Eight Dimensions of Quality. Harvard Business Review, 65(6). http://dx.doi.org/10.1225/87603

Grimm, M. (1992). Fast food, could this actually be the end of the price wars? Adweek Midwest, Suppl. Adweek, Brandweek, Mediaweek, 72-73.

Gujarati, D. N. (2003). Basic Econometrics (4th ed.). New York: McGraw-Hill/Irwin, (Chapter 10).

Han, C. M. (1989). Country Image: Halo or Summary Construct? Journal of Marketing Research, 26(2), 222-229. http://dx.doi.org/10.2307/3172608

Han, C. M., \& Terpstra, V. (1988). Country-of-Origin Effects for Uni-National and Bi-National Products. Journal of International Business Studies, 19(2), 235-255. http://dx.doi.org/10.1057/palgrave.jibs.8490379

Hong, S. T., \& Wyer, R. S. (1989). Effects of Country-of-Origin and Product-Attribute Information on Product Evaluation: An Information Processing Perspective. Journal of Consumer Research, 16(2), 175-187. http://dx.doi.org/10.1086/209206

Hong, S. T., \& Wyer, Jr. R. S. (1990). Determinants of product evaluation: Effects of the time interval between knowledge of a product's country of origin and information about its specific attributes. Journal of Consumer Research, 17, 277-288. http://dx.doi.org/10.1086/208557

Hui, M. K., \& Zhou, L. (2003). Country-of-manufacture effects for known brands. European Journal of Marketing, 37(1/2), 133-153. http://dx.doi.org/10.1108/03090560310458664

Hulland, J. S. (1999). The Effects of Country-of-Brand and Brand Name on Product Evaluation and Consideration: A Cross-Country Comparison. Journal of International Consumer Marketing, 11(1), 23-40. http://dx.doi.org/10.1300/J046v11n01_03

Iyer, G. R., \& Kalita, J. K. (1997). The Impact of Country of Origin and Country of Manufacture Cues on Consumer Perceptions of Quality and Value. Journal of Global Marketing, 11(1), 7-28. http://dx.doi.org/10.1300/J042v11n01_02

Jain, S. C. (2007). State of the art of international marketing research: Directions for the future. Journal for Global Business Advancement, 1(1), 4-19. http://dx.doi.org/10.1504/JGBA.2007.012546

Johansson, J. K. (1989). Determinants and effects of the use of 'made in' labels. International Marketing Review, 6(1), 47-58. http://dx.doi.org/10.1108/EUM0000000001502

Johansson, J. K., \& Nebezahl, I. D. (1986). Multinational Production: Effect on Brand Value. Journal of International Business Studies, 17(3), 101-126. http://dx.doi.org/10.1057/palgrave.jibs.8490861

Kleinbaum, D. G., Kupper, L. L., \& Muller, K. E. (1988). Applied regression analysis and other multivariate 
methods (2nd ed.). Boston: PWS-Kent.

Maheswaran, D. (1994). Country-of-Origin as a Stereotype: Effects of Consumer Expertise and Attribute Strength on Product Evaluations. Journal of Consumer Research, 21, 354-365. http://dx.doi.org/10.1086/209403

Papadopoulos, N., \& Heslop, L. A. (1993). Product-Country Images: Impact and Role in International Marketing. Binghampton, NY: International Business Press.

Papadopoulos, N. (2004). Place branding: Evolution, meaning, and implications. Place Branding, 1(1), 36-49. http://dx.doi.org/doi:10.1057/palgrave.pb.5990003

Papadopoulos, N., Heslop, L. A., \& Bamossy, G. (1990). A comparative image analysis of domestic versus imported products. International Journal of Research in Marketing, 16(7), 283-94. http://dx.doi.org/10.1016/0167-8116(90)90005-8

Papadopoulos, N., Marshall, J. J., \& Heslop, L. A. (1988). Strategic implications of product and country images: a modeling approach. European Society for Opinion and Marketing Research, Lisbon, pp. 69-90.

Parameswaran, R., \& Yaprak, A. (1987). A Cross-National Comparison of Consumer Research Measures. $\begin{array}{lllll}\text { Journal of International Business } & \text { Studies, } & \text { 18(Spring), }\end{array}$ http://dx.doi.org/10.1057/palgrave.jibs. 8490398

Park, B. (2012). States of origin: Where cars come from. Retrieved April 10, 2012, from http://news.drive.com.au/drive/motor-feature/states-of-origin-where-cars-come-from-20120405wdps.html

Peterson, R. A., \& Jolibert, A. J. P. (1995). A meta-analysis of country-of-origin effects. Journal of International Business Studies, 26(4), 883-897. http://dx.doi.org/10.1057/palgrave.jibs.8490824

Pharr, J. M. (2005). Synthesizing Country-of-Origin Research from the Last Decade: Is the Concept Still Salient in an Era of Global Brands? Journal of Marketing Theory and Practice, 13(4), 34-45.

Phau, I., \& Chao, P. (2008). Country-of-origin: state of the art review for international marketing strategy and practice. International Marketing Review, 25(4), 349-53.

Saporito, B. (1992). Why the price wars never end. Fortune, 125(6), 68-78.

Schooler, R. D. (1965). Product bias in the Central American common market. Journal of Marketing Research, November, 394-397. http://dx.doi.org/10.2307/3149486

Serwer, A. E. (1995). Will Timberland grow up. Fortune, 131(10).

Sharma, P. (2011). Country of origin effects in developed and emerging markets: exploring the contrasting roles of materialism and value consciousness. Journal of International Business Studies, 42(2), 285-306. http://dx.doi.org/10.1057/jibs.2010.16

Srinivasan, N., Jain, S. C., \& Sikand, K. (2004). An experimental study of two dimensions of country-of-origin(manufacturing country and branding country) using intrinsic and extrinsic cues. International Business Review, 13(1), 65-82. http://dx.doi.org/10.1016/j.ibusrev.2003.05.004

Tan, C. T., \& Farley, J. U. (1987). The impact of cultural patterns on cognition and intention in Singapore. Journal of Consumer Research, 13(March), 540-544. http://dx.doi.org/10.1086/209087

Thakor, M. V., \& Kohli, C. S. (1996). Brand Origin: Conceptualization and Review. Journal of Consumer Marketing, 13(3), 27-42. http://dx.doi.org/10.1108/07363769610147929

Thakor, M. V., \& Lavack, A. M. (2003). Effect of perceived brand origin associations on consumer perceptions of quality. Journal of Product \& Brand Management, 12(6), 394-407. http://dx.doi.org/10.1108/10610420310498821

Theil, H. (1978). Introduction to econometrics. N.J: Prentice Hall,

Tse, D. K., \& Gorn, G. J. (1993). An Experiment on the Salience of Country-of-Origin in the Era of Global Brands. Journal of International Marketing, 1(1), 57-76.

Usunier, J. C. (2006). Relevance in business research: the case of country-of-origin research in marketing. European Management Review 3, 60-73. http://dx.doi.org/10.1057/palgrave.emr.1500049

Usunier, J. C. (2011). The shift from manufacturing to brand origin: suggestions for improving COO relevance. International Marketing Review, 28(5), 486-496. http://dx.doi.org/10.1057/10.1108/02651331111167606

Verlegh, P. W., \& Steenkamp, J. (1999). A review and meta-analysis of country-of-origin research. Journal of 
Economic Psychology, 20, 521-46. http://dx.doi.org/10.1016/S0167-4870(99)00023-9

Welch, J. F. (1994). Global competitiveness: American in the eye of the hurricane. Exec Speeches, 8(6), 39-42.

Witt, J., \& Rao, C. P. (1992). The Impact of Global Sourcing on Consumers: Country-of-Origin Effects on Perceived Risk. Journal of Global Marketing, 6(3), 105-128. http://dx.doi.org/10.1300/J042v06n03_06

Yaprak, A., \& Ravi, P. (1986). Strategy Formulation in Multinational Marketing: A Deductive Paradigm-Integrating Approach. Advances in International Marketing, 1, 21-45.

Colyer, E. (2005). Beer brands and homelands. Retrieved July 15, 2009, from http://www.brandchannel.com/features_effect.asp?pf_id=250 